\title{
Phase Equilibria in the System $\mathrm{MgO}-\mathrm{TiO}_{2}$
}

\author{
L. W. Coughanour and V. A. DeProsse
}

\begin{abstract}
The phase relations in the system $\mathrm{MgO}^{-\mathrm{TiO}_{2}}$ were studied by means of solid-phase reactions between the components and by observing the fusion characteristics of specimens within the system. The existence of three binary compounds in the system was confirmed From the data obtained, an equilibrium diagram for the system is suggested.
\end{abstract}

\section{Introduction}

A study of phase-equilibrium relationships in the system $\mathrm{MgO}-\mathrm{ZrO}_{2}-\mathrm{TiO}_{2}$ has been initiated in connection with a fundamental study of ceramic dielectrics. ${ }^{1}$ A survey of the literature pertinent to the problem revealed several discrepancies in the published data on the subordinate binary systems. It was, therefore, considered essential that a preliminary study of the binary systems be made.

An equilibrium diagram for the $\mathrm{MgO}^{-} \mathrm{TiO}_{2}$ system was first published in 1932 by von Wartenberg and Prophet [1]. ${ }^{2}$ Two compounds, $2 \mathrm{MgO} \cdot \mathrm{TiO}_{2}$ and $\mathrm{MgO} \cdot 2 \mathrm{TiO}_{2}$, were postulated. The subsequent work of other investigators [2] showed, however, that there are three binary compounds in the system. They are the two listed by von Wartenberg plus $\mathrm{MgO} \cdot \mathrm{TiO}_{2}$. This compound occurs in nature as the mineral geikielite.

The existence of three compounds in the system was confirmed in the present work by means of solidphase reactions between the components $\mathrm{MgO}$ and $\mathrm{TiO}_{2}$. These reactions took place at various temperatures between $1,200^{\circ}$ and $1,550^{\circ} \mathrm{C}$. The completeness of reaction and compound formation was observed petrographically and by means of X-ray diffraction patterns of the fired samples.

The determination of the fusion point of each of the three compounds and of the solidus and liquidus temperatures at various points across the system supplied data from which a revised equilibrium diagram was constructed.

\section{Sample Preparation and Test Methods}

The following materials were used as components in the preparation of samples for this study.

$\mathrm{MgO}$ - Water-clear crystals of Norton Co. artificial periclase of nominal purity over 99 percent were selected. The crystals were ground with a mullite mortar and pestle to pass a 325 mesh screen. A spectrogram of the ground material showed only weak lines for the principal impurities, $\mathrm{Al}, \mathrm{Si}$, and Ti.

$\mathrm{TiO}_{2}$ - Highly purified titania of nominal purity over 99.9 percent was used. This material was secured from the Titanium Division of the National Lead Co. A spectrogram indicated that the principal impurities, $\mathrm{Si}, \mathrm{Cu}$, and $\mathrm{Al}$, were present in amounts less than 0.01 percent.

Calculations of weight composition were made to

1 This fundamental study is sponsored by the Department of the Army, Office of Ordnance Research.

${ }^{2}$ Figures in brackets indicate literature references at the end of this paper. \pm 0.01 percent, no correction being made for the percentage of purity of the components.

The components in sufficient amounts to makea $10 \mathrm{~g}$ sample were weighed to the nearest milligram and mixed in the dry condition by shaking in a large container. They were then mixed with approximately 5 percent by weight of a 5 -percent solublestarch solution binder, and 1-in. diameter disks were formed in a hardened steel mold at a pressure of 5,000 $\mathrm{lb} / \mathrm{in}^{2}$. The pressed disks were calcined for 4 to 16 hr at $1,200^{\circ} \mathrm{C}$. During heating the disks rested on platinum foil. Oxidizing conditions were maintained by the use of platinum-wound or Globar resistor airatmosphere furnaces. After cooling, the disks were pulverized using a mullite mortar and pestle, the powdered material was remixed with starch solution binder, and repressed at $5,000 \mathrm{lb} / \mathrm{in}^{2}{ }^{2}$. The repressed disks were then refired for 4 to $5 \mathrm{hr}$ at $1,350^{\circ} \mathrm{C}$, again under oxidizing conditions. Petrographic examination, supplemented by X-ray analysis, showed that solid-phase reactions between the components were essentially complete after these two heat treatments.

Following the second calcination the disks were reground, remixed with binder, and disks about $1 / 4$ in. high were formed at $15,000 \mathrm{lb} / \mathrm{in}^{2}$ in a $1 / 2$-in.-diameter mold. From these disks the actual fusion test specimens were ground in the form of small four-sided pyramids, grooved on each side [3]. The fusion tests and softening-range tests were carried out in a thoria resistor furnace [4]. The specimens were placed in the furnace on a disk of a platinum-rhodium alloy. The metal disk was, in turn, on a support of $\mathrm{ThO}_{2}$ or $\mathrm{BeO}$. The heating rate during the tests was about $3 \mathrm{deg} \mathrm{C} / \mathrm{min}$ until the solidus temperature was approached, when it was reduced to about $2 \mathrm{deg} \mathrm{C} / \mathrm{min}$. Oxidizing conditions were maintained by slight convection currents of air through the furnace. The temperature and the fusion characteristics of the specimens were observed with an optical pyrometer calibrated at the National Bureau of Standards. The melting point of pure platinum wire was observed as a spot check on the pyrometer calibration. Agreement within $2 \mathrm{deg} \mathrm{C}$ of the accepted value of $1,769^{\circ} \mathrm{C}$ on the 1948 International Temperature Scale was obtained.

In the determination of the solidus and liquidus temperatures of the test specimens, the first sign of liquid formation, rounding of the corners of the test pyramid, was recorded as the solidus temperature. The temperature of complete fusion, as observed through the optical pyrometer, was considered to be the liquidus temperature. 
In such determinations, there are several possible sources of error. These include the slight deviation from black-body conditions, the introduction of minute quantities of impurities in the forming and grinding of the specimens, the slight reduction of the $\mathrm{TiO}_{2}$ on heating, and the inherent difficulty in the visual observation of fusion characteristics.

In the oxide-resistor furnaces used for the fusion tests, black-body conditions were rather closely approached. In order to render the grooved pyramid specimen visible in outline, it was necessary to have a slightly concave surface on the metal disk on which the sample rested during heating. This concave metal surface reflected less light to the pyrometer than the sample did, giving the disk the appearance of being slightly cooler than the specimen.

Partial reduction of the titanates was observed in compositions richer in $\mathrm{TiO}_{2}$ than $\mathrm{MgO} \cdot \mathrm{TiO}_{2}$ when the specimens were quenched or cooled rapidly. It is probable, therefore, that at high temperatures and during the fusion tests there was some loss of oxygen from the samples. This loss might be thought of as introducing a minute quantity of a third component, or impurity, into the samples. It is believed that the error introduced into the fusion-point measurements by this reduction is not significant. Neither by petrographic nor X-ray methods was it possible to detect any evidence of the formation of a lower oxide of titania, even in specimens that had been quenched and were a dark-gray color. This would tend to indicate that the amount of reduction is small. Agamawi and White [5] conducted a weight-loss test on rutile at various temperatures up to $1,550^{\circ} \mathrm{C}$. They reached the conclusion that the oxygen loss, on heating rutile in air, is practically negligible. Likewise, Moore [6] showed that, for single crystals of rutile, less than 0.1 -percent reduction caused a marked color change.

Probably the largest source of error in the fusionpoint measurements was in the problem of selecting the solidus and liquidus points by visual observation. The accuracy would depend upon the viscosity of the melts, the composition, and its relation to a eutectic point or compound, and the experience and judgment of the observer. In this particular system, the fusion of compositions richer than $2 \mathrm{MgO} \cdot \mathrm{TiO}_{2}$ in $\mathrm{MgO}$ was difficult to observe due to the high viscosity of the melts.

Considering these various factors, it is believed that the recorded temperatures are correct to \pm 10 deg C.

After the fused specimens had cooled in the furnace, they were analyzed with the petrographic microscope. Such examination was facilitated by the wide difference in the optical properties of the various compounds in the system, and by the fact that large well-formed crystals were obtained. The optical properties of the compounds may be tabulated as follows:

\begin{tabular}{|c|c|c|}
\hline Compound & $\begin{array}{l}\text { Optical } \\
\text { character }\end{array}$ & $\begin{array}{l}\text { Approximate indices of } \\
\text { refraction }\end{array}$ \\
\hline $\begin{array}{l}\mathrm{MgO} \\
2 \mathrm{MgO} \cdot \mathrm{TiO}_{2} \\
\mathrm{MgO} \cdot \mathrm{TiO}_{2} \\
\mathrm{MgO} \cdot 2 \mathrm{TiO}_{2} \\
\mathrm{TiO}_{2}\end{array}$ & $\begin{array}{l}\text { Isotropic..- } \\
\text { do. } \\
\text { negative. } \\
\text { B i a x i a l } \\
\text { negative. } \\
\text { Uniaxial } \\
\text { positive. }\end{array}$ & $\begin{array}{l}\eta=1.736 \\
\eta=1.959 \\
\epsilon=1.95, \omega=2.28 \\
\alpha=2.11, \beta=2.19, \gamma=2.23 \\
\epsilon=2.903, \omega=2.616\end{array}$ \\
\hline
\end{tabular}

TABLE 1. Fusion characteristics of compositions in the system $\mathrm{MgO}-\mathrm{TiO}_{2}$

\begin{tabular}{|c|c|c|c|c|c|c|}
\hline \multicolumn{4}{|c|}{ Compositions } & \multicolumn{2}{|c|}{ Effect of heating } & \multirow{3}{*}{$\begin{array}{l}\text { Results of petrographic examination } \\
\text { (Specimens examined were not } \\
\text { quenched and the phases observed } \\
\text { may not be those in equilibrium at } \\
\text { the liquidus). }\end{array}$} \\
\hline \multicolumn{2}{|c|}{ Mole } & \multicolumn{2}{|c|}{ Weight } & \multirow{2}{*}{$\begin{array}{l}\text { Fusion } \\
\text { started }\end{array}$} & \multirow{2}{*}{$\begin{array}{c}\text { Fusion } \\
\text { completed }\end{array}$} & \\
\hline $\mathrm{MgO}$ & $\mathrm{TiO}_{2}$ & $\mathrm{MgO}$ & $\mathrm{TiO}_{2}$ & & & \\
\hline $\begin{array}{l}\% \\
90 \\
80 \\
77 \\
75 \\
73\end{array}$ & $\begin{array}{l}\% \\
10 \\
20 \\
23 \\
25 \\
27\end{array}$ & $\begin{array}{l}\% \\
81.95 \\
66.87 \\
63.63 \\
60.22 \\
57.24\end{array}$ & $\begin{array}{c}\% \\
18.05 \\
33.13 \\
36.37 \\
39.78 \\
42.76\end{array}$ & $\begin{array}{c}{ }^{\circ} \mathrm{C} \\
1,708 \\
1,705 \\
1,708 \\
1,707\end{array}$ & $\begin{array}{c}{ }^{\circ} \mathrm{C} \\
-1,741 \\
1,727 \\
1,726 \\
1,728\end{array}$ & $\begin{array}{l}\mathrm{MgO}+2 \mathrm{MgO} \cdot \mathrm{TiO}_{2} . \\
\text { Do. } \\
\text { Do. } \\
\text { Do. } \\
\text { Do. }\end{array}$ \\
\hline $\begin{array}{l}70 \\
66.7 \\
63 \\
60 \\
57\end{array}$ & $\begin{array}{l}30 \\
33.3 \\
37 \\
40 \\
43\end{array}$ & $\begin{array}{l}54.23 \\
50.24 \\
46.37 \\
43.08 \\
40.23\end{array}$ & $\begin{array}{l}45.77 \\
49.78 \\
53.63 \\
56.91 \\
59.77\end{array}$ & $\begin{array}{l}1,709 \\
1,732 \\
1,580 \\
1,587 \\
1,581\end{array}$ & $\begin{array}{l}1,727 \\
1,732 \\
1,726 \\
1,685 \\
1,600\end{array}$ & $\begin{array}{l}\text { Do. } \\
2 \mathrm{MgO} \cdot \mathrm{TiO}_{2}+\mathrm{MgO} \cdot \mathrm{TiO}_{2} \text { (trace). } \\
2 \mathrm{MgO} \cdot \mathrm{TiO}_{2}+\mathrm{MgO} \cdot \mathrm{TiO}_{2} \text {. } \\
\text { Do. } \\
\text { Do. }\end{array}$ \\
\hline $\begin{array}{l}53 \\
50 \\
47 \\
43 \\
40\end{array}$ & $\begin{array}{l}47 \\
50 \\
53 \\
57 \\
60\end{array}$ & $\begin{array}{l}36.41 \\
33.55 \\
31.04 \\
27.69 \\
25.17\end{array}$ & $\begin{array}{l}63.59 \\
66.45 \\
68.96 \\
72.31 \\
74.83\end{array}$ & $\begin{array}{l}1,583 \\
1,629 \\
1,589 \\
1,591 \\
1,592\end{array}$ & $\begin{array}{l}1,615 \\
1,631 \\
1,611 \\
1,598 \\
1,619\end{array}$ & $\begin{array}{l}\text { Do. } \\
\mathrm{MgO} \cdot \mathrm{TiO}_{2}+\mathrm{MgO} \cdot 2 \mathrm{TiO}_{2} \text { (trace). } \\
\mathrm{MgO} \cdot \mathrm{TiO}_{2}+\mathrm{MgO} \cdot 2 \mathrm{TiO}_{2} \text {. } \\
\text { Do. } \\
\text { Do. }\end{array}$ \\
\hline $\begin{array}{l}37 \\
33.3 \\
30 \\
27 \\
25\end{array}$ & $\begin{array}{l}63 \\
66.7 \\
70 \\
73 \\
75\end{array}$ & $\begin{array}{l}22.97 \\
20.15 \\
17.87 \\
16.33 \\
14.39\end{array}$ & $\begin{array}{l}77.03 \\
79.86 \\
82.13 \\
83.67 \\
85.61\end{array}$ & $\begin{array}{l}1,594 \\
1,652 \\
1,608 \\
1,605 \\
1,608\end{array}$ & $\begin{array}{l}1,635 \\
1,652 \\
1,642 \\
1,639 \\
1,628\end{array}$ & $\begin{array}{l}\text { Do. } \\
\mathrm{MgO} \cdot 2 \mathrm{TiO}_{2} \\
\mathrm{MgO} \cdot 2 \mathrm{TiO}_{2}+\mathrm{TiO}_{2} \\
\text { Do. } \\
\text { Do. }\end{array}$ \\
\hline $\begin{array}{l}23 \\
20 \\
18 \\
15 \\
12\end{array}$ & $\begin{array}{l}77 \\
80 \\
82 \\
85 \\
87\end{array}$ & $\begin{array}{r}12.85 \\
11.20 \\
9.72 \\
8.22 \\
6.44\end{array}$ & $\begin{array}{l}87.15 \\
88.80 \\
90.28 \\
91.78 \\
93.56\end{array}$ & $\begin{array}{l}1,607 \\
1,608 \\
1,607 \\
1,605 \\
1,609\end{array}$ & $\begin{array}{l}1,638 \\
1,622 \\
1,615 \\
1,612 \\
1,635\end{array}$ & $\begin{array}{l}\text { Do. } \\
\text { Do. } \\
\text { Do. } \\
\text { Do. } \\
\mathrm{MgO} \cdot 2 \mathrm{TiO}_{2}+\mathrm{TiO}_{2} \text {. }\end{array}$ \\
\hline
\end{tabular}


For the biaxial compound $\mathrm{MgO} \cdot 2 \mathrm{TiO}_{2}, 2 \mathrm{~V}$ was estimated, from interference figures, to be $70^{\circ}$ to $75^{\circ}$. Calculation of $2 \mathrm{~V}$ from the indices of refraction gave a value of $68^{\circ}$.

The results of the fusion tests and of the petrographic analysis of the nonquenched specimens are listed in table 1.

\section{Results and Comparisons With Previous Work}

The equilibrium diagram for the system as determined by von Wartenberg is shown in figure 1 . That constructed from the results of the present study is shown in figure 2. Comparison of the two diagrams shows that, apart from the introduction of the third compound, the major difference between the two is the lower fusion points obtained in the present study. It is believed that these temperature differences are explained simply by the greater refinement of the methods used in the study covered by this report.

Other fusion-point data published on the system are extremely limited in extent. The fusion point of the compound $\mathrm{MgO} \cdot 2 \mathrm{TiO}_{2}$ was determined by Sigurdson and Cole $[2, \mathrm{e}]$ to be $1,645^{\circ} \mathrm{C}$ under oxidizing conditions. This is in excellent agreement with the presently determined value of $1,652^{\circ} \mathrm{C}$. St. Pierre [7] determined the fusion point of highly purified $\mathrm{TiO}_{2}$ to be $1,840^{\circ} \pm 10^{\circ} \mathrm{C}$, again under oxidizing conditions. This value, also, is in excellent agreement with the value $1,839^{\circ} \mathrm{C}$ observed in the present study.

Büssem, et al. $[2, \mathrm{a}]$ conducted an X-ray investigation of the system. They did not determine an equilibrium diagram, but they did obtain results that indicated, to them, the existence of a hightemperature solid solution of $\mathrm{MgO}$ in $2 \mathrm{MgO}^{\mathrm{T}} \mathrm{TiO}_{2}$. They selected compositions in the area between

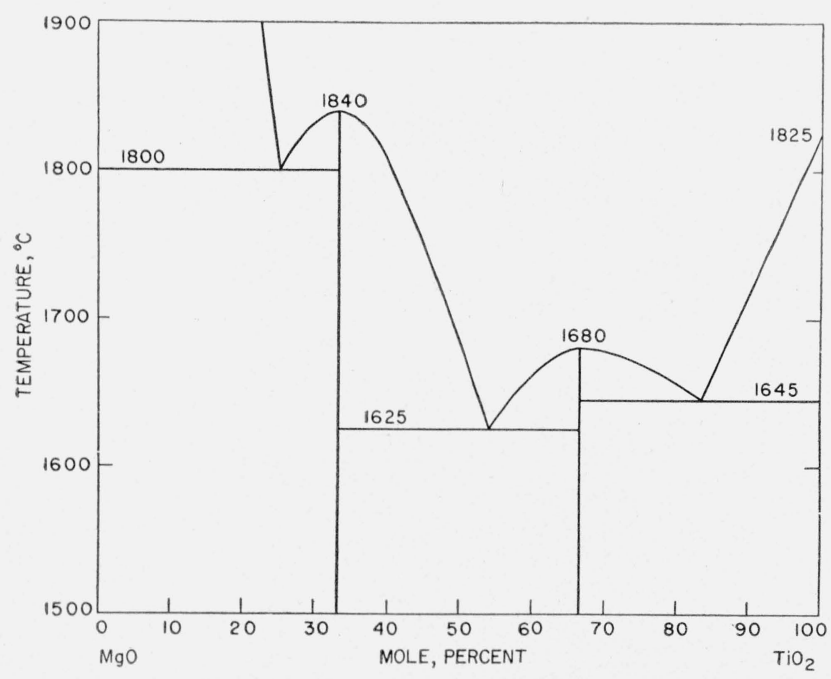

Figure 1. $\mathrm{MgO}-\mathrm{TiO}_{2}$ system; after von Wartenberg, reference [1].
$\mathrm{MgO}$ and $2 \mathrm{MgO} \cdot \mathrm{TiO}_{2}$ and heated them to approximately $1,460^{\circ} \mathrm{C}$. They then compared the X-ray powder patterns of the cooled samples with the patterns of mechanical mixtures of the same over-all compositions, the mechanical mixtures being prepared from the components $\mathrm{MgO}$ and $2 \mathrm{MgO} \cdot \mathrm{TiO}_{2}$. They noted that the diffraction lines of $\mathrm{MgO}$ were sharper and clearer for the mixtures than for the heated compositions. This effect they attributed to a high-temperature solid solution of $\mathrm{MgO}$ in $2 \mathrm{MgO} \cdot \mathrm{TiO}_{2}$ with an unmixing or exsolution reaction on cooling. The unmixing was thought to result in extreme subdivision of the $\mathrm{MgO}$ grains with the subsequent lack of sharpness in the $\mathrm{MgO}$ diffraction lines.

A similar test was made during the present study on the composition $4 \mathrm{MgO}: \mathrm{TiO}_{2}$. The results obtained were negative, there being no significant differences in the diffraction patterns of the heated sample and of the mechanical mixture.

Several attempts were made in the present study to detect solid-solution formation in the system. Particular attention was given to the high $\mathrm{MgO}$ portion of the system, in order to verify or disprove the existence of the high-temperature solid solution of $\mathrm{MgO}$ in $2 \mathrm{MgO} \cdot \mathrm{TiO}_{2}$ postulated by Büssem. In one method, samples high in $\mathrm{MgO}$ content $\left(9 \mathrm{MgO}: \mathrm{TiO}_{2}\right.$, $4 \mathrm{MgO}: \mathrm{TiO}_{2}, 3 \mathrm{MgO}: \mathrm{TiO}_{2}$ ) which had been previously calcined were used. Portions of the calcines were heated for $2 \mathrm{hr}$ at $1,400^{\circ} \mathrm{C}$ and for $1 / 2 \mathrm{hr}$ at $1,650^{\circ} \mathrm{C}$ and were cooled slowly. The cooled samples were examined petrographically and by means of $\mathrm{X}$-rays. The petrographic examination showed that the index of refraction of $\mathrm{MgO}$, and of $2 \mathrm{MgO} \cdot \mathrm{TiO}_{2}$, had not deviated from its normal value in either case. In addition, the $\mathrm{MgO}$ grains did not have the appearance of having undergone an unmixing reaction. X-ray diffraction patterns showed no significant intensity variations or parameter changes.

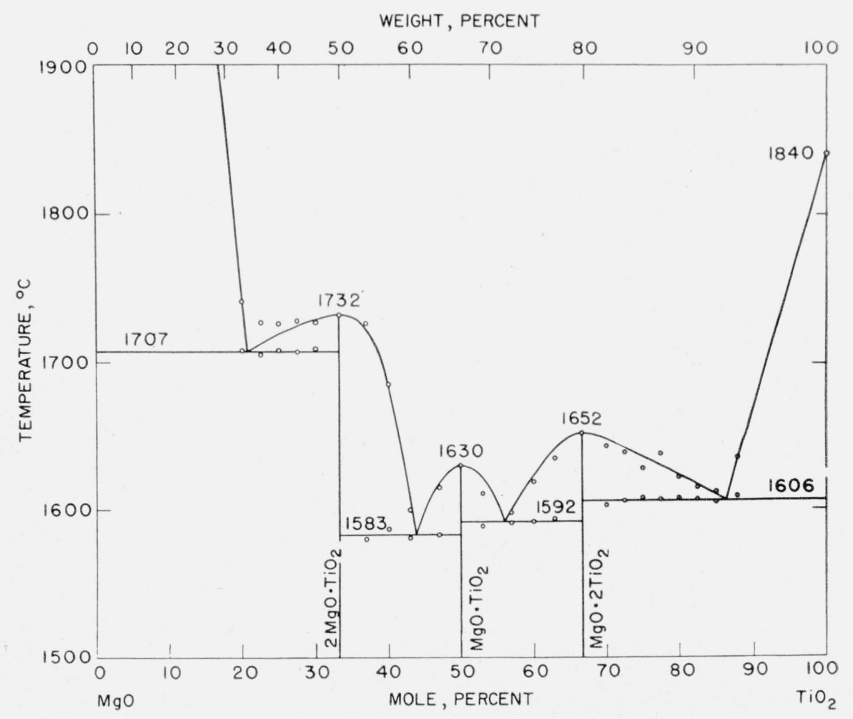

Figure 2. Proposed diagram for the $\mathrm{MgOTi}_{2} \mathrm{O}_{2}$ system. 
In another attempt to verify any solid-solution formation, specimens of the same compositions were heated to $1,460^{\circ}$ or $1,500^{\circ} \mathrm{C}$ and the temperature was maintained constant for $3 \mathrm{hr}$. The specimens were then quenched in water. Again, petrographic examination of the quenched specimens showed no change in the index of refraction of either $\mathrm{MgO}$ or $2 \mathrm{MgO} \cdot \mathrm{TiO}_{2}$. The results of these tests indicate that there is no solid-solution formation between $2 \mathrm{MgO} \cdot \mathrm{TiO}_{2}$ and $\mathrm{MgO}$. Index of refraction measurements of these two compounds were accurate to about 2 units in the third decimal $( \pm 0.002)$. With this degree of accuracy, solid solution formation to the extent of 1 percent could have been detected.

Similar tests at various points on the diagram failed to indicate any solid solutions in the system. Finally, the fact that the solidus lines obtained are horizontal is indicative of the absence of solid-solution formation.

\section{Summary and Conclusions}

Twenty-six compositions in the system $\mathrm{MgO}-\mathrm{TiO}_{2}$ were prepared. They were studied from the standpoints of solid-phase reactions and fusion behavior. The existence of three binary compounds in the system was confirmed. They are $2 \mathrm{MgO} \cdot \mathrm{TiO}_{2}$, $\mathrm{MgO} \cdot \mathrm{TiO}_{2}$, and $\mathrm{MgO} \cdot 2 \mathrm{TiO}_{2}$. Their melting points were determined to be $1,732^{\circ}, 1,630^{\circ}$, and $1,652^{\circ} \mathrm{C}$, respectively. Four eutectic points were located as follows: 21-mole percent of $\mathrm{TiO}_{2}$, and $1,707^{\circ} \mathrm{C}$; 44-mole percent of $\mathrm{TiO}_{2}$, and $1,583^{\circ} \mathrm{C}$; 56-mole percent of $\mathrm{TiO}_{2}$ and $1,592^{\circ} \mathrm{C}$; and 86 -mole percent of $\mathrm{TiO}_{2}$ and $1,606^{\circ} \mathrm{C}$. No evidence of solid-solution formation was obtained. From these data, an equilibrium diagram for the system is suggested.

This work was sponsored by the Office of Ordnance Research, Department of the Army.

All X-ray analyses for the project were performed by R. S. Roth.

\section{References}

[1] H. von Wartenberg and E. Prophet, Z. anorg. Chem. 208, 373 (1932).

[2] (a) W. Büssem, C. Schusterius, and A. Ungewiss, Ber. deut. keram. Ges. 18, 433 (1937);

(b) W. Jander and K. Bunde, Z. anorg. Chem. 239, 418 (1938);

(c) Y. Tanaka, Bul. Chem. Soc. Japan 60, 212 (1939);

(d) H. A. McKinstry, C. F. Hocker, W. R. Ricker, W. H. Earhart, N. R. Thielke, and E. C. Henry, Quarterly Progress Report on the Investigation of Refractory Materials, School of Mineral Industries, Pennsylvania State College (May 15, 1949);

(e) H. Sigurdson and S. S. Cole, J. Metals 1, No. 12, Trans. 905 (1949).

[3] R. F. Geller, P. J. Yavorsky, B. L. Steierman, and A. S. Creamer, J. Research NBS 36, 277 (1946) RP1703.

[4] (a) R. F. Geller, J. Research NBS 27, 555 (1941) RP1443;

(b) S. M. Lang and R. F. Geller, J. Am. Ceram. Soc. 34, 193 (1951).

[5] Y. M. Agamawi and J. White, Trans. Brit. Ceram. Soc. 51, 293 (1951).

[6] C. H. Moore, Jr., Trans. Am. Inst. Mining Met. Eng. 184, 194 (1949); Mining Eng. 1, 194 (1949); Tech. Pub. No. 2617.

[7] P. O. S. St. Pierre, J. Am. Ceram. Soc. 35, 188 (1952).

Washington, May 7, 1953. 